UDC 66.011:258.094.3:725.3/727.4

\title{
MATHEMATICAL DESCRIPTION FOR THE OXIDATIVE DEHYDROGENATION OF ISOPROPANOL TO ACETONE
}

\author{
A.M.Aliyev, A.R.Safarov, E.F.Aliyev \\ M.Nagiyev Institute of Catalysis and Inorganic Chemistry, NAS of Azerbaijan \\ agil_s@mail.ru
}

Received 05.11.2020

Accepted 17.12.2020

\begin{abstract}
The paper presents the results of the development of the complete mathematical model for the oxidative dehydrogenation of isopropanol to acetone on the metal-zeolite catalyst - CuPd-mordenite. Using the kinetic model of this process have been chosen the optimal type of reactor. Have been identified the most significant physicochemical phenomena significantly affect to the process. The mathematical description of this process consists of the heat balance equation, as well as an equation that takes into account the pressure drop in the system at the gas mixture moving through a fixed-bed catalyst.
\end{abstract}

Keywords: isopropanol, acetone, mathematical description, heat balance, heat effects, pressure drop.

doi

\section{Formulation of the problem}

The world production of acetone is over 6.9 million tons per year and is growing steadily. Acetone is used as a raw material for the synthesis of many important chemical products, used as a solvent in the production of lacquers, explosives, medicines etc. [1].

One of the main industrial methods for producing acetone is the oxidative dehydrogenation of isopropyl alcohol in the vapor phase. On using a copper catalyst, the process is carried out at a temperature of $500^{\circ} \mathrm{C}$ and a pressure of $3 \mathrm{~atm}$ [2]. This method of conducting the process is quite energy-intensive and requires the search for new ways to obtain this product.

To this regard, the gas-phase oxidation of isopropyl alcohol to acetone on the metalzeolite catalysts synthesized by ion exchange was first studied the M.F.Nagiyev Institute of Chemical Problems. It was found that a metalzeolite catalyst $\mathrm{CuPd}$-mordenite with a content of 0.5 mass. $\% \mathrm{Cu}^{2+}$ and 0.1 mass. $\% \mathrm{Pd}^{2+}$ exhibits relatively high activity in this reaction [3]. Kinetic experimental studies were carried out on the developed catalyst in the following parameter ranges: temperature $-(150-180)^{0} \mathrm{C}$, volume velocity - $(1000-2500) \mathrm{h}^{-1}$, partial pressures: $P_{i-\mathrm{C}_{3} \mathrm{H}_{7} \mathrm{OH}}-(0.10-0.51) \cdot 10^{5} \mathrm{~Pa}, P_{\mathrm{O}_{2}}-$
$(0.1-0.5) \cdot 10^{5} \mathrm{~Pa}$. They allowed us to propose a kinetic scheme and the following grossstoichiometric equations for the formation of acetone and carbon dioxide from isopropanol:

$$
\begin{aligned}
& i-\mathrm{C}_{3} \mathrm{H}_{7} \mathrm{OH}+\frac{1}{2} \mathrm{O}_{2} \rightarrow \mathrm{CH}_{3}-\mathrm{CO}-\mathrm{CH}_{3}+\mathrm{H}_{2} \mathrm{O}, \\
& i-\mathrm{C}_{3} \mathrm{H}_{7} \mathrm{OH}+4.5 \mathrm{O}_{2} \rightarrow 3 \mathrm{CO}_{2}+4 \mathrm{H}_{2} \mathrm{O} .
\end{aligned}
$$

Based on the conducted kinetic experimental studies and analysis of literature materials, a stage scheme of the mechanism of the gas-phase oxidation of isopropyl alcohol to acetone was proposed and a theoretically justified kinetic model of the process was developed. So the equation of the rate of formation of acetone was presented in the following form:

$$
r_{\mathrm{AC}}=k_{1} P_{\mathrm{O}_{2}}\left\{\frac{\sqrt{1+2\left(\frac{k_{1} P_{\mathrm{O}_{2}}}{k_{2} P_{\mathrm{C}_{3} \mathrm{H}_{7} \mathrm{OH}}}+\frac{k_{1} P_{\mathrm{O}_{2}}}{k_{3}}\right)}-1}{\left(\frac{k_{1} P_{\mathrm{O}_{2}}}{k_{2} P_{\mathrm{C}_{3} \mathrm{H}_{7} \mathrm{OH}}}+\frac{k_{1} P_{\mathrm{O}_{2}}}{k_{3}}\right)}\right\}^{2} .
$$

For carbon dioxide, the rate of formation has the form:

$$
r_{\mathrm{CO}_{2}}=\frac{k_{4} K_{1} K_{2} P_{\mathrm{O}_{2}} P_{i-\mathrm{C}_{3} \mathrm{H}_{7} \mathrm{OH}}}{\left(1+K_{1} P_{\mathrm{O}_{2}}+K_{2} P_{i-\mathrm{C}_{3} \mathrm{H}_{7} \mathrm{OH}}\right)^{2}}
$$

$K_{1}, K_{2}$ - corresponding constants of adsorption equilibrium of oxygen and isopropyl alcohol, $1 / \mathrm{Pa} ; k_{1}, k_{2}, k_{3}, k_{4}$ - velocity constants corre- 
sponding to the stage index, $\mathrm{mol} /\left(\mathrm{kg}_{\mathrm{cat}} \cdot \mathrm{h}\right)$; $P_{i-\mathrm{C}_{3} \mathrm{H}_{7} \mathrm{OH}}, P_{\mathrm{O}_{2}}-$ corresponding partial pressure of isopropyl alcohol and acetone, $\mathrm{Pa}$; $r_{\mathrm{AS}}, r_{\mathrm{CO}_{2}}$ - corresponding rates of formation of acetone and carbon dioxide, $\mathrm{mol} /\left(\mathrm{kg}_{\mathrm{cat}} \mathrm{h}\right)$.

The picture of running chemical transformations at the micro level, i.e. according to the laws of classical chemical kinetics, it sharply differs from such one in production conditions. In real apparatuses the chemical reaction is influenced by the accompanying physical processes conditioned by the heat, mass transfer and the hydrodynamic environment in them. So, for the industrial implementation of this process, it is necessary to develop its mathematical description. This in turn, requires the selection of the optimal type of reactor element, theoretical optimization based on the kinetic equation, the development of a heat balance equation and an equation that takes into account the pressure drop along the length of the reactor. The purpose of this study is to develop a complete mathematical model of the process of oxidative dehydrogenation of isopropyl alcohol into acetone using a selected active metal-zeolite catalyst.

\section{Development of a mathematical model}

In mathematical modeling, first of all, it is necessary to find out the form of the mathematical model, which is determined by the type of reactor selected. Therefore, at drawing up a mathematical model, the description of the flow of substances becomes particularly important. As is known, the main typical models that characterize the hydrodynamic flow include the model of ideal displacement and ideal mixing, carried out, respectively, in displacement and mixing reactors. Chemical reactors can be compared using various methods. In particular, for this purpose, it is convenient to select a parameter that determines the operation and efficiency of the reactor, and evaluate the value of this parameter for the types of reactors under consideration.

The optimal reactor type was selected based on the kinetics equation of this process. Computer simulation of the process of oxidative conversion of isopropanol to acetone was studied in a single reactor of ideal mixed-flow $\left(\mathrm{V}_{\text {i.m- } \mathrm{f}}\right)$ and in a reactor of ideal plug-flow $\left(\mathrm{V}_{\text {i.p-- }}\right)$ under identical conditions. Calculations have shown that the coefficient of use of the reaction volume for all degrees of conversion in the ideal mixedflow reactor is greater than in the ideal plug-flow reactor. In addition, it was found that with an increase in the degree of conversion from 60 to $80 \%$, the ratio of the volumes of the studied $\mathrm{V}_{\text {i.m-f }} / \mathrm{V}_{\text {i.p-f }}$ reactors increases from 1.15 to 1.85 . Similar results are also obtained for other reaction conditions. Also, studies on the kinetic model showed that with an increase in the degree of conversion, the selectivity for the target product decreases slightly.

Thus, based on the above mentioned results, it can be concluded that for the process of oxidative conversion of isopropanol to acetone, an ideal plug-flow reactor is optimal, the best approximation of which is a reactor with a fixed-bed catalyst.

At given process parameters (catalyst density $\rho_{\text {cat }}=850 \mathrm{~kg} / \mathrm{m}^{3}$, linear flow rate $u=5$ $\mathrm{m} / \mathrm{s}$, capacity for the main product $-6.5 \mathrm{t} / \mathrm{h}$ ) and also calculated on the basis of the kinetic equation (catalyst mass $G_{\text {cat }}=6000 \mathrm{~kg}$, volumetric flow rate: $V_{\text {flow }}=15 \mathrm{~m}^{3} / \mathrm{h}$ ) allowed us to determine the structural dimensions of the reactor element:

- reactor volume: $V_{\text {reac }}=G_{\text {cat }} / \rho_{\text {cat }}=7.05 \mathrm{~m}^{3}$;

- reactor cross-sectional area: $S=3 \mathrm{~m}^{2}$;

- diameter and length of the rector:

$$
\begin{gathered}
D=\sqrt{\frac{4 S}{\pi}}=1.95 \mathrm{~m} \\
l=\frac{V_{\text {reac }}}{S}=2.35 \mathrm{~m}
\end{gathered}
$$

Theoretical optimization was carried out according to the following criteria:

$$
\max Q=\left\{T, n_{\mathrm{C}_{3} \mathrm{H}_{7} \mathrm{OH}}^{0}, n_{\mathrm{O}_{2}}^{0}, V, X, A_{\mathrm{C}_{3} \mathrm{H}_{6} \mathrm{O}}\right\}
$$

with the following restrictions on process parameters:

$$
\begin{gathered}
140^{\circ} \mathrm{C} \leq T \leq 200^{\circ} \mathrm{C} \\
85 \leq X \leq 95 \\
1800 \leq V \leq 2500
\end{gathered}
$$


where $Q$ - reactor capacity on acetone, $\mathrm{kg} / \mathrm{h} ; T-$ reactor temperature, ${ }^{0} \mathrm{C} ; A_{\mathrm{C}_{3} \mathrm{H}_{6} \mathrm{O}}$ - acetone yield, $\% ; \mathrm{V}$ - volume velocity, $\mathrm{h}^{-1} ; X$ - degree of conversion, $\% ; n_{\mathrm{C}_{3} \mathrm{H}_{7} \mathrm{OH}}^{0}, n_{\mathrm{O}_{2}}^{0}-$ initial values of isopropyl alcohol and oxygen, $\mathrm{mol} / \mathrm{h}$.

The optimization problem was solved using the "Search" software system [4]. When optimizing the process using the kinetic equation in the above stated intervals of changing parameters there were found: the optimal temperature of the process $-180^{\circ} \mathrm{C}$; volume velocity -2000 $\mathrm{h}^{-1}$; the degree of conversion of isopropyl alcohol is $91 \%$; the yield of acetone is $86 \%$; the yield of carbon dioxide is $5 \%$; $Q=6.54 \mathrm{t} / \mathrm{h}$.

To develop a complete mathematical model, we will highlight the main elementary processes that significantly affect the course of the process. In the process under consideration, there are no temperature and velocity gradients in the direction perpendicular to the flow movement. The change of temperature, composition of the reacting environment and pressure occurs along the reactor. The pressure loss is caused by the presence of resistances that the gas mixture must overcome when passing through the fixed-bed catalyst. So, while developing the mathematical model, temperature gradients, pressure drop, and changes in the composition of the reacting medium occurring along the reactor were taken into account.

The heat balance equation of any process or apparatus is based on the law of conservation of energy [5], according to which the amount of heat entering this process, if the latter does not convert it into another type of energy, is equal to the amount of heat released during the process. The heat balance equation took into ac- count the loss of heat to the environment and the thermal effects of chemical reactions:

$$
\frac{\mathrm{d} T}{\mathrm{~d} G_{\mathrm{cat}}}=-\frac{\sum_{j=1}^{2} r_{j} \Delta H_{\mathrm{R} j}}{\sum_{i=1}^{6} n_{i} C_{p i}}-\frac{\alpha\left(T-T_{x}\right)}{\sum_{i=1}^{6} n_{i} C_{p i}},
$$

where $r_{j}$ - formation rates of acetone and carbon dioxide, $\mathrm{mol} / \mathrm{kg}_{\text {cat }} \cdot \mathrm{h} ; \Delta H_{\mathrm{R} j}$ - value of the thermal effect of the $\mathrm{j}$ reaction, $\mathrm{kJ} / \mathrm{mol} ; C_{p i}(i=\overline{1,6})$ - the values of the heat capacities of the process components: acetone, isopropyl alcohol, oxygen, carbon dioxide, water and helium, $\mathrm{kJ} / \mathrm{mol} \cdot \mathrm{K} ; \alpha-$ heat transfer coefficient, $\mathrm{kJ} / \mathrm{mol} \cdot \mathrm{K} \cdot \mathrm{h} ; T_{x}-$ ambient temperature, $\mathrm{K} ; T$ - temperature of the gas mixture, $\mathrm{K} ; G-$ the amount of catalyst, $\mathrm{g} ; n_{i}-$ the mole velocity of the $i$ component, $\mathrm{mol} / \mathrm{h}$.

Table shows the values of the empirical coefficients of the heat capacity of all substances [5] involved in this process, and their heat of formation.

Using the formulas [5]:

1) isobaric component-wise heat capacity:

$$
C_{p i}=a_{i}+b_{i} T+c_{i} T^{2}+d_{i} T^{3}
$$

2) changes in the isobaric heat capacity of the system:

$$
\begin{aligned}
& \Delta C_{p j}=\Delta a_{j}+\Delta b_{j} T+\Delta c_{j} T^{2}+\Delta d_{j} T^{3}= \\
& \left(\sum_{i} v_{i}^{\prime} a_{i}^{\text {r.p }}-\sum_{i} v_{i} a_{i}^{\text {st.s }}\right)+\left(\sum_{i} v_{i}^{\prime} b_{i}^{\text {r.p }}-\sum_{i} v_{i} b_{i}^{\text {st.s }}\right) T+ \\
& +\left(\sum_{i} v_{i}^{\prime} c_{i}^{\text {r.p }}-\sum_{i} v_{i} c_{i}^{\text {st.s }}\right) T^{2}+\left(\sum_{i} v_{i}^{\prime} d_{i}^{\text {r.p }}-\sum_{i} v_{i} d_{i}^{\text {st.s }}\right) T^{3}
\end{aligned}
$$

3) the standard heat of the $j$-th reaction:

$$
\Delta H_{0 j}=\left(\sum_{i} v_{i}^{\prime} \Delta H_{0 i}^{\text {r.p }}-\sum_{i} v_{i} \Delta H_{0 i}^{\text {st.s }}\right)_{j} ;
$$

Values of standard heat build-up and heat capacities

\begin{tabular}{|l|c|c|c|c|c|}
\hline \multirow{2}{*}{ Substance, $i$} & $\begin{array}{c}\text { Standard heat build-up } \Delta H_{0 i}, \\
\mathrm{~kJ} / \mathrm{mol}\end{array}$ & \multicolumn{3}{|c|}{ Coefficients temperature dependences of heat capacities } \\
\cline { 3 - 6 } & 0 & $a$ & $b$ & $c$ & $d$ \\
\hline Oxygen & -241.83 & 6.713 & $-0.879 \cdot 10^{-6}$ & $4.170 \cdot 10^{-6}$ & $-2.544 \cdot 10^{-9}$ \\
\hline Water & -393.5 & 7.701 & $4.495 \cdot 10^{-4}$ & $2.521 \cdot 10^{-6}$ & $-0.859 \cdot 10^{-9}$ \\
\hline Carbon dioxide & 0 & 4.728 & $1.754 \cdot 10^{-2}$ & $-1.338 \cdot 10^{-5}$ & $4.097 \cdot 10^{-9}$ \\
\hline Helium & -272.42 & 7.440 & $-0.324 \cdot 10^{-2}$ & $4.4 \cdot 10^{-6}$ & $-2.79 \cdot 10^{-9}$ \\
\hline Isopropanol & -217.5 & 7.745 & $4.502 \cdot 10^{-2}$ & $1.53 \cdot 10^{-5}$ & $-2.212 \cdot 10^{-8}$ \\
\hline Acetone & & 1.505 & $6.224 \cdot 10^{-2}$ & $-2.99 \cdot 10^{-5}$ & $4.86 \cdot 10^{-9}$ \\
\hline
\end{tabular}


4) heats of the $j$-th reaction:

$$
\begin{aligned}
& \Delta H_{\mathrm{Rj}}=\int_{0}^{T} \Delta C_{p j} \mathrm{~d} T+\Delta H_{0 j}=\Delta a_{j} T+\frac{1}{2} \Delta b_{j} T^{2}+ \\
& +\frac{1}{3} \Delta c_{j} T^{3}+\frac{1}{4} \Delta d_{j} T^{4}-\frac{\Delta c^{\prime}}{T}+\Delta H_{0 j},
\end{aligned}
$$

as well as the values of standard formation heats and empirical heat capacity coefficients $\Delta \mathrm{H}_{0 \mathrm{i}}$ from table 1 , we determined the values of standard formation heats $\Delta \mathrm{H}_{0 \mathrm{j}}$ and temperature dependences of thermal effects $\Delta \mathrm{H}_{\mathrm{Rj}}$ for all reactions involved in the process, according to their stoichiometric schemes. Here $v_{\mathrm{i}}$ and $v_{\mathrm{i}}^{\prime}$ stoichiometric coefficients of the $i$-th component in the starting substances and in the reaction products; $\Delta \mathrm{H}_{0 \mathrm{i}}^{\text {st.s }}, \Delta \mathrm{H}_{0 \mathrm{i}}^{\mathrm{r} . \mathrm{p}}$ standard heat buildup of the $i$-th component in the starting materials and reaction products; $\Delta \mathrm{H}_{\mathrm{Rj}}$ - thermal effect of the $j$-th reaction; $\Delta \mathrm{H}_{0 \mathrm{j}}-$ standard heat buildup of the $j$-th reaction.

1) for the acetone formation reaction:

$$
\begin{gathered}
i-\mathrm{C}_{3} \mathrm{H}_{7} \mathrm{OH}+\frac{1}{2} \mathrm{O}_{2} \rightarrow \mathrm{CH}_{3}-\mathrm{CO}-\mathrm{CH}_{3}+\mathrm{H}_{2} \mathrm{O}, \\
\Delta H_{01}=-186.2 \mathrm{~kJ} / \mathrm{mol}, \\
\Delta H_{\mathrm{R} 1}=-186200-1.8955-0.01767 T- \\
-4.4764 \cdot 10^{-5} T^{2}+2.739 \cdot 10^{-8} T^{3},
\end{gathered}
$$

2) for the carbon dioxide formation reaction:

$$
i-\mathrm{C}_{3} \mathrm{H}_{7} \mathrm{OH}+4.5 \mathrm{O}_{2} \rightarrow 3 \mathrm{CO}_{2}+\mathrm{H}_{2} \mathrm{O} \text {, }
$$

similarly, we obtain the values of the standard heat build-up and the temperature dependence of the thermal effect:

$$
\begin{gathered}
\Delta H_{02}=-1150 \mathrm{~kJ} / \mathrm{mol} \\
\Delta H_{\mathrm{R} 2}=-1150 \cdot 10^{3}-16.0685-0.00805 T- \\
-7.1684 \cdot 10^{-5} T^{2}+4.5 \cdot 10^{-8} T^{3} .
\end{gathered}
$$

The flow of ingredients in flow-through reactors is accompanied by pressure losses. Although the pressure loss is insignificant, in order to obtain a more correct and accurate distribution of the reaction product yields along the length of the reactor, it is necessary to take it into account. The loss of head, or pressure, is caused by both friction resistance and local resistances. The equation proposed by Ergun [7] describes very well the experimental data of various authors on the resistance in the layer, and was used in the construction of a mathematical model for calculating the pressure loss along the length of the rector. It looks like this:

$$
\frac{\mathrm{dP}}{\mathrm{dl}}=-\left(\frac{150}{\operatorname{Re}}+1.75\right) \cdot \frac{\rho_{\mathrm{gas}} \mathrm{u}_{0}^{2}(1-\varepsilon)}{\mathrm{d}_{\mathrm{p}} \mathrm{g} \varepsilon^{3}},
$$

Re - Reynolds number, $\operatorname{Re}=\frac{\mathrm{d}_{\mathrm{p}} \rho_{\mathrm{gas}} \mathrm{u}_{0}}{\mu(1-\varepsilon)} ; \mathrm{D}-$ diameter of the reactor; $\rho_{\text {gas }}-$ gas density, $\mathrm{kg} / \mathrm{m}^{3} ; \mathrm{g}-$ free fall acceleration, $\mathrm{m} / \mathrm{s}^{2} ; \mathrm{u}_{0}-$ linear flow rate, $\mathrm{m} / \mathrm{s} ; \mathrm{dP}$ - the equivalent particle diameter, $\mathrm{m}$; $\varepsilon$ - porosity, $\mathrm{b} / \mathrm{r} ; \mu$ - the gas viscosity, $\mathrm{kg} / \mathrm{m} \cdot \mathrm{s} ; 1-$ length of reactor, $\mathrm{m}$.

The equations of the kinetic model (2-3), heat balance (5), and pressure loss (6) form a complete mathematical model of the oxidation of isopropanol to acetone. It will be presented as a single system as follows:

$$
\begin{aligned}
& \left\{\frac{n_{i-\mathrm{C}_{3} \mathrm{H}_{7} \mathrm{OH}}^{0}}{\rho_{\text {cat. }} \cdot \frac{\pi D^{2}}{4}} \frac{\mathrm{d} A_{1}}{\mathrm{~d} l}=k_{1} P_{\mathrm{O}_{2}}\left\{\frac{\sqrt{1+2\left(\frac{k_{1} P_{\mathrm{O}_{2}}}{k_{2} \mathrm{P}_{i-\mathrm{C}_{3} \mathrm{H}_{7} \mathrm{OH}}}+\frac{k_{1} P_{\mathrm{O}_{2}}}{k_{3}}\right)}-1}{\left(\frac{k_{1} P_{\mathrm{O}_{2}}}{k_{2} P_{i-\mathrm{C}_{3} \mathrm{H}_{7} \mathrm{OH}}}+\frac{k_{1} P_{\mathrm{O}_{2}}}{k_{3}}\right)}\right\}^{2}\right. \\
& \left\{\frac{n_{i-\mathrm{C}_{3} \mathrm{H}_{7} \mathrm{OH}}^{0}}{\rho_{\text {cat. }} \cdot \frac{\pi D^{2}}{4}} \frac{\mathrm{d} A_{2}}{\mathrm{~d} l}=\frac{k_{4} K_{1} K_{2} P_{\mathrm{O}_{2}} P_{i-\mathrm{C}_{3} \mathrm{H}_{7} \mathrm{OH}}}{\left(1+K_{1} P_{\mathrm{O}_{2}}+K_{2} P_{i-\mathrm{C}_{3} \mathrm{H}_{7} \mathrm{OH}}\right)^{2}}\right. \\
& \begin{array}{l}
\frac{4}{\rho_{\text {cat. }} \pi D^{2}} \frac{\mathrm{d} T}{\mathrm{~d} l}=-\frac{\sum_{j=1}^{2} r_{j} \Delta H_{\mathrm{R} j}}{\sum_{i=1}^{6} n_{i} C_{p i}}-\frac{\alpha\left(T-T_{\mathrm{x}}\right)}{\sum_{i=1}^{6} n_{i} C_{p i}} \\
\frac{\mathrm{d} P}{\mathrm{~d} l}=-\left(\frac{150}{\mathrm{Re}}+1.75\right) \cdot \frac{\rho_{\mathrm{gas}} u_{0}^{2}(1-\varepsilon)}{d_{p} g \varepsilon^{3}}
\end{array}
\end{aligned}
$$

$\mathrm{A}_{1}, \mathrm{~A}_{2}$ are the yields of acetone, carbon dioxide, $\mathrm{d} / \mathrm{l}$.

A slight exothermic effect of the reaction (the temperature increases by $150^{\circ} \mathrm{C}$ ) and a small pressure drop indicate the possibility of using an adiabatic reactor.

\section{Conclusion}

The developed mathematical model will be used in the future to solve the problems of optimal control of the reactor element of oxidative dehydrogenation of isopropanol into acetone. 


\section{References}

1. Zakoshanskii V.M. Fenol i atceton. SPb.: Himizdat, 2009. $608 \mathrm{~s}$.

2. Lebedev N.N. Himiia i tekhnologiia osnovnogo organicheskogo i neftehimicheskogo sinteza. M.: Himiia, 1981. $608 \mathrm{~s}$.

3. Aliev A.M., Matiev K.I., Safarov A.R., Guseinova A.M. Podbor aktivnogo modifitcirovannogo tceolitnogo katalizatora i kinetika reaktcii okisleniia izopropilovogo spirta v atceton. Azerb. Chem. J. 2014. № 4. S. 9-17.
4. Shakhtakhtinskii T.N., Bakhmanov M.F., Kelbaliev G.I. Metody optimizatcii protcessov himicheskoi tekhnologii $\mathrm{s}$ programmami dlia EVM. Baku: Elm, 1985. $260 \mathrm{~s}$.

5. Beskov S.D. Tekhno-himicheskie raschety. M.: Goshimizdat, 1950. $560 \mathrm{~s}$.

6. Rid R., Prausnitc Dzh., Shervud T. Svoistva gazov i zhidkostei. Spravochnoe posobie. Per. s angl. pod red. B.I.Sokolova. - 3-e izd., pererab. i dop. L.: Himiia, 1982. $592 \mathrm{~s}$.

7. Veilas S. Himicheskaia kinetika i raschety promyshlennykh reaktorov. M.: Himiia, 1967. $416 \mathrm{~s}$.

\section{IZOPROPANOLUN ASETONA OKSIDLOŞDİRICI DEHIDROGENLOŞMO PROSESININ RIYAZI MODELININ QURULMASI}

\section{A.M.Oliyev, A.R.Səfərov, E.F.Oliyev}

Məqalədə CuPd-mordenit metalseolit katalizatoru üzərində izopropanolun asetona oksidləşdirici dehidrogenləşmə prosesinin tam riyazi modelinin yaradılmasının nəticələri göstərilib. Prosesin kinetik modeli əsasında reaktorun optimal tipi seçilib. Prosesin gedişinə əhəmiyyətli dərəcədə təsir edən ən mühüm fiziki-kimyəvi faktorlar müəyyən olunub. Bele $\mathrm{ki}$, tədqiq edilən prosesin riyazi təsviri ozündə istilik balans tənliyini və, həmçinin, qaz qarışı̆ıının tərpənməz lay katalizatordan keçərkən sistemdəki təzyiq itkisini nəzərə alan tənliyi özündə birləşdirib.

Açar sözlor: izopropanol, aseton, riyazi təsvir, istilik balansl, istilik effekti, təzyiqin düşməsi.

\section{МАТЕМАТИЧЕСКОЕ ОПИСАНИЕ ОКИСЛИТЕЛЬНОГО ДЕГИДРИРОВАНИЯ ИЗОПРОПАНОЛА В АЦЕТОН}

\section{А.М.Алиев, А.Р.Сафаров, Э.Ф.Алиев}

В статье приведены результаты разработки полной математической модели процесса окислительного дегидрирования изопропанола в ацетон на металлцеолитном катализаторе $\mathrm{CuPd}$-морденит. $\mathrm{C}$ использованием кинетической модели процесса осуществлен выбор оптимального типа реактора. Выявлены наиболее значимые физико-химические явления, существенным образом влияющие на ход процесса. Математическое описание исследуемого процесса составляют уравнения теплового баланса, а также уравнение, учитывающее потерю напора в системе при движении газовой смеси через неподвижный слой катализатора.

Ключевые слова: изопропанол, аиетон, математическое описание, тепловой баланс, тепловые эффекты, падение давления. 